\title{
Blowing the Coals of Ambition Hubert Languet, Giordano Bruno and Antonio Pérez as Marginal Hero-Makers in the Sidney-Essex Circle
}

\author{
Andreas Schlüter
}

When Robert Devereux, the second Earl of Essex, had his promising career and extraordinary life terminated in 1601 on behalf of Queen Elizabeth I, on the scaffold of the Tower of London, charged with high treason against his monarch and patroness, an "unprecedented output of ballads, madrigals and elegies"1 publicly lamented the earl's death. Even though his martyr-like calm demeanour before the execution was widely admired, ${ }^{2}$ many contemporaries would have preferred a rather more traditionally martial death. ${ }^{3}$ Barbabe Barnes, for example, wished that Essex "might have died in the warres upon the enemies of his countrey, that I might heroically with good cheere have registered his death in there offices" ${ }^{4} \mathrm{Ob}$ viously, many considered the Earl of Essex a hero, a magnificent figure whose downfall was felt all the more for his greatness, and this discrepancy called for explanations.

One rather unremarkable member of Essex's inner circle, Robert Naunton, would, a few years later, blame the earl's fall on those close to him: Naunton viewed - apart from Essex's military clientele - "his family, his servants and his owne creatures, which were bound by the rule of safety", as those who were "to helpe on his Catastrophe", for "they blew the coales of his ambition, and infused into him too much of the spirit of glory". ${ }^{5}$ Robert Naunton went on to assert that "this multitude that followes you will either devoure you, or undoe you". ${ }^{6}$ For Naunton, the social embeddedness of the heroic figure is obviously the key to understanding it.

1 G. Ungerer, A Spaniard in Elizabethan England, Vol. 2 (Colección Támesis A; 54), London 1976, p. 364. See also A. Tipton, The Transformation of the Earl of Essex. PostExecution Ballads and "The Phoenix and the Turtle", in: Studies in Philology 99, 2002, pp. $57-80$.

2 M. James, Society, Politics and Culture. Studies in Early Modern England, Cambridge 1986, pp. 455-458; for an interpretation of the actual events, stressing the "saintliness" of the earl's death in his popular afterlife: p. 462.

3 On the changing notions of what constituted the right death for a nobleman not only in France, see H. Germa-Romann, Du "bel mourir" au "bien mourir". Le sentiment de la mort chez les gentilshommes français (1515-1643), Geneva 2001.

4 B. Barnes, Foure Bookes of Offices, London 1606, p. 181.

5 R. Naunton, Fragmenta Regalia, London 1641 (Repr. London 1824), p. 123.

6 Ibid. 


\section{A Social Figuration in Need of a Hero}

Many scholars would agree with this. According to them, there is no hero without a group of worshippers or a public that believes in the capacity of the heroic figure to do some extraordinary deed with significance and relevance to their lives. Obviously, this social figuration ${ }^{7}$ was in need of a heroic figure that could be projected on a living person who would lead this group. As Geoffrey Cubitt and Allen Warren have argued, it is within "frameworks of institutional and social practice" that "rhetorical and intellectual manoeuvres" are carried out which "convert individuals into bearers of heroic status". ${ }^{8}$ The group Naunton described was in need of a heroic figure they could turn their aspirations and wishes to, "the object of some kind of collective emotional investment". ${ }^{9}$ The social group that turned Essex into a heroic figure was an aristocratic faction at the court of Queen Elizabeth.

In the growing crisis of the last decades of Elizabeth's reign, the "monarchical republic" with ample space and opportunity for the courtier aristocracy was starting to diminish; from the mid 1570s to the "nasty nineties" there was a need for the aristocratic circles at court to reinvent themselves and to regain cultural hegemony ${ }^{10}$ by asserting a symbolic dominance - they were in need of the "courtieras-hero" (Jennifer Low). ${ }^{11}$ For this to happen, these groups and their aspiring focal point of identification - in other words, the heroic figure ${ }^{12}$ - needed intellectual stimulus for this hero to capture and to transport this cultural innovation.

Thus, there was a need for hero-makers for these focal persons, for the aspiring courtier Philip Sidney (until his untimely death after his first battle in the Netherlands, fighting for England and the Calvinist Dutch against Spain, aged 31, in 1586) and for Robert Devereux, second Earl of Essex, who took over Sidney's status within this group ${ }^{13}$ and continued to lead this circle until his death on the

7 I use the term "figuration" in accordance with R. von den Hoff [et al.], Helden - Heroisierungen - Heroismen. Transformationen und Konjunkturen von der Antike bis zur Moderne. Konzeptionelle Ausgangspunkte des Sonderforschungsbereichs 948, in: helden. heroes. héros. E-Journal on Cultures of the Heroic 1, Issue 1, 2013, DOI 10.6094/ helden.heroes.heros./2013/01/03, pp. 7-14, here p. 9.

8 G. Cubitt / A. Warren, Introduction, in: G. Cubitt / A. Warren (eds.), Heroic Reputations and Exemplary Lives, Manchester/New York 2000, pp. 1-27, here p. 4.

9 Ibid., p. 3.

10 The term "cultural dominance" in connection with the nobility of the early $17^{\text {th }}$ century is used by R. G. Asch, Zwischen defensiver Legitimation und kultureller Hegemonie. Strategien adliger Selbstbehauptung in der frühen Neuzeit, in: Zeitenblicke 4, Issue 2, 2005, http://www.zeitenblicke.de/2005/2/Asch, 10 June 2015. I will refrain from discussing the theoretical implications and conceptual questions in detail here.

11 J. Low, Manhood and the Duel. Masculinity in Early Modern Drama and Culture, Houndmils 2003, pp. 22-27.

12 See von den Hoff [et al.], Helden - Heroisierungen - Heroismen (footnote 7), pp. 8-9.

13 R. Wood, "Cleverly playing the Stoic". The Earl of Essex, Sir Philip Sidney and Surviving Elizabeth's Court, in: A. Connolly / L. Hopkins (eds.), Essex. The Cultural Impact of an 
scaffold in 1601. They were surrounded by a circle of people that had formed in the 1570s when the former favourite of Queen Elizabeth, Robert Dudley, Earl of Leicester, joined with other eminent courtiers to form a group with a political agenda: pursuing an aggressive foreign policy, intent on defending the cause of the Protestant confession all across Europe, and thus fighting against Spain and the other Catholic powers such as the papal state in Italy.

This group was helping the "intellectual bombardment" 14 that opened up English elites to the developments on the continent after the culturally "drab age" of the mid-Tudor period (C. S. Lewis). The heroic figure generated in this "cultural revolution" was "committed to defending and enhancing the reformed religion in England, and to doing this in part by cultural intervention". ${ }^{15}$ The circle's hero would become "a powerful cultural token, a figure through whom subsequent generations might propagate and contest significant values", ${ }^{16}$ as Alan Sinfield notes for Philip Sidney. The heroised person himself would be at the forefront of this process, Sidney by styling himself in his writings, which was some of the most important literature of the Elizabethan age, Essex in performative self-heroisation. I have elaborated on this self-fashioning elsewhere and will focus on the heroisation by others here. ${ }^{17}$

Here, I will look at those who were charged with the task of blowing the coals of ambition for this group's would-be heroes Sidney and Essex. But, as I shall argue and depart from Naunton here, it was neither a multitude that blew anyone's ambitions here nor the people who were tied to their heroised master for a long time by bonds of affection and patronage. I will focus on one particular and, arguably, the most important - set of hero-makers in this figuration: 'marginal men' from the continent, who, each in his own way, helped in creating, shaping and fashioning the heroic figure of the Sidney-Essex circle - Hubert Languet (1518-1581) in the 1570s and Giordano Bruno (1548-1600) in the 1580s, both with Philip Sidney, and Antonio Pérez (1540-1611) in the 1590s, with Sidney's successor, the Earl of Essex. They were instrumental in moulding the heroic figure in an innovative way, providing intellectual impulses and aesthetic splendour, thus retaining or regaining the cultural dominance attached to the aristocratic circle these hero-makers tried to influence.

Elizabethan Courtier, Manchester/New York 2013, pp. 25-46, here p. 41: "direct line of political and cultural inheritance".

14 G. F. Waller, "This Matching of Contraries". Bruno, Calvin and the Sidney Circle, in: Neophilologus 56, Issue 3, 1972, pp. 331-343, here p. 331.

15 A. Sinfield, Faultlines. Cultural Materialism and the Politics of Dissident Reading, Oxford 1992, pp. 184-185.

16 Ibid., p. 210.

17 For one particular aesthetic strategy for self-heroisation, see A. Schlüter, Humouring the Hero. The Uses of Melancholy among Military Nobles in Late Elizabethan England, in: helden. heroes. héros. E-Journal on Cultures of the Heroic, Special Issue 1, 2014, DOI 10.6094/helden.heroes.heros./2014/QM/04, pp. 24-34. 
I will argue that all three men I focus on here are important for the heroisation of the Sidney/Essex figure exactly because of their marginal status. After establishing why these marginal figures became hero-makers, I will explore the forms, media and content of their heroisations.

\section{Experts of the Threshold: Marginal Intellectuals Shaping Liminal Heroes}

\subsection{Marginal Men in Misery}

The people who construct and worship a hero figure do so, as the sociologist Hans Speier has formulated following Max Weber's conception of charisma, in "a devout, wholly personal surrender pyschologically born out of misery and hope". 18 In the following, I will first trace the misery and hope of the marginal hero-makers to find out why they chose to enter into and influence this heroic figuration.

These three men had each been born into prosperous families which they abandoned, instead embarking on promising yet perenially unstable intellectual careers: All three had managed to assume important positions in the political or cultural arena, and all three had been put into precarious positions after losing track at some point and had been on the move for quite some time, becoming constant wanderers.

Languet was the first-born son of a wealthy and well-to-do noble family in Burgundy. He refused to take on the family heritage and ventured into academic humanism. From then on, he was often travelling Western Europe, never staying anywere for long, until he made the acquaintance of Philipp Melanchthon, who was to shape his whole personality, outlook and circle of friends. After Melanchthon's death, Languet became the centre of a network of like-minded Protestant humanists from different countries. ${ }^{19}$ In the subsequent diplomatic service of different high-ranking rulers like the elector of Saxony, Languet travelled often and extensively to France and to other destinations, so that his biographer Beatrice Nicollier-de Weck found Languet's life to be "austere, almost nomadic". ${ }^{20}$ Melanchthon likened him to Odysseus for his restless wandering and knowledge, quoting Homer: "Truly, 'Of many men he saw the cities and knew the minds.".21 Whilst Languet always maintained an elevated social position in the company of

18 H. Speier, Risk, Security, and Modern Hero Worship, in: H. Speier, The Truth in Hell and Other Essays on Politics and Culture, 1935-1987, Oxford/New York 1989, pp. 117-134, here p. 119.

On Languet's biography: B. Nicollier-de Weck, Hubert Languet (1518-1581). Un réseau politique internationale de Melanchthon à Guillaume d'Orange, Geneva 1995.

20 Ibid., p. 335, transl. mine.

21 K. G. Bretschneider (ed.), Corpus reformatorum, Halle 1841, Vol. 8, col. 263, Melanchthon to Johannes Bretschneider, 1 April 1551, transl. mine. 
important rulers, he would never find a permanent residence again. He met and befriended Philip Sidney most likely in Paris in 1572, just some weeks before the catastrophe of St Bartholomew's Night. ${ }^{22}$ They started an extended and frequent correspondence which would last from 1573 to 1580 and which would co-create the heroic figure of Philip Sidney.

Bruno was born in Nola close to Naples, as the son of a soldier, and was expelled from a monastery which he was about to join permanently. Instead, he chose to wander through Italy, Geneva and France, disputing scholars and authorities, debating exciting new ideas of the infinite universe, everywhere in conflict and trouble with - intellectual and political - authorities. ${ }^{23}$ In his selffashioning, ${ }^{24}$ Bruno showed himself to be constantly on the move: In the "Ash Wednesday Supper", he asserted that "for the true philosopher every land is his country", ${ }^{25}$ and he was to say later in his farewell speech at Wittenberg: "In brief toil I felt prolonged repose, in mild pain immense joy, and in short exile a boundless homeland" ${ }^{26}$ This temporary homeland was, after he had stayed at Henri III's court for some time, England, where he lived for less than two years, from 1583 to 1585, and where he - occasionally - met Philip Sidney and his already heroising circle, to which he added his own heroic flavour.

Pérez, (probably) an extramarital child of a senior official at Philip II's Spanish court, had left the enormously prestigious and powerful position of secretary to Philip II, the most important ruler of his time, for accusations of murder, and went to France and eventually to England to seek protection and intellectual satisfaction from the highest ranks of courtly society. ${ }^{27}$ "Peregrino", wanderer, was one of his self-fashionings; he once asserted: "My fate it is to wander." 28 Also in the coded language of the Essex circle, he was called "Raphael Peregrino". Coming from the patronage of Henri IV and still "on loan" from him, Pérez moved to England for almost two years, from 1593 to 1595, and again for some months in 1596, staying permanently with Essex and his circle for this time, co-fashioning the heroic figure the earl had already started to become.

22 Nicollier-de Weck, Hubert Languet (footnote 19), p. 329.

23 For a short sketch of Bruno's life, see A. D. Imerti, Editor's Introduction, in: G. Bruno, The Expulsion of the Triumphant Beast, ed. and transl. A. D. Imerti, Lincoln, NE/London 1992, pp. 1-63.

24 I use this term in the same sense as S. Greenblatt, Renaissance Self-Fashioning. From More to Shakespeare, Chicago 1980.

25 Imerti, Editor's Introduction (footnote 23), p. 19.

26 W. von Koppenfels, Ash Wednesday in Westminster. Giordano Bruno meets Elizabethan England, in: A. Höfele / W. von Koppenfels (eds.), Renaissance Go-Betweens. Cultural Exchange in Early Modern Europe (Spectrum Literaturwissenschaft; 2), Berlin/New York 2005, pp. 55-77, here p. 58.

27 For Pérez's biography, the seminal work is still G. Marañón, Antonio Pérez, 2 Vols., Buenos Aires 1947.

28 Ungerer, A Spaniard in Elizabethan England, Vol. 2 (footnote 1), pp. 331-332. 


\subsection{Marginals, Liminars and the Sacred Core of Society}

The three men who connected in different ways to a circle of important English courtiers were marginal men, as Robert E. Parks has called them. In what follows, I will outline this concept further by connecting the marginal man with Victor Turner's concept of the liminal space, in which communitas is achieved.

A marginal man is a "cultural hybrid, a man living and sharing intimately in the cultural life and traditions of two distinct peoples; never quite willing to break [...] with his past and his traditions, and not quite accepted [...] in the new society in which he now sought to find a place". ${ }^{29}$ This position, Parks asserts, allows the marginal man to explore intellectual spaces in a liberated way, giving him the chance for creativity: A marginal is "the individual with the wider horizon, the keener intelligence, the more detached and rational viewpoint", who can interact between different spheres and cultures, thus allowing for cultural exchange. ${ }^{30}$ But this marginal has negative traits, as well: He takes a permanently unstable position beyond the boundaries of the norms and usages of a given culture in which he finds himself. Therefore, he is prone to remain maladjusted and insecure in his migrant state. ${ }^{31}$

To resolve this unstableness, a marginal may seek support from another conceptual figure that enters the space beyond everyday life: the liminar, as Victor Turner has called him, who can also be found in this unstable and potentially dangerous state. Turner explains: "Marginals like liminars are also betwixt and between". The only difference he sees is that "unlike ritual liminars they have no cultural assurance of a final stable resolution of their ambiguity". ${ }^{32}$ Thus, for the liminar, the space behind the boundary is a liminal space. Victor Turner introduced the concept of the liminal sphere or space in order to make sense of a social mechanism which, in his view, determined the way a social group connected through ritual to a space outside of the profane. This is the liminal space in which the sacred resides. The concept is based on Emil Durkheim's idea of the dichotomous separation of two spheres that lie at the core of any given society, the sacred and the profane, which he laid out in his foundational work "The Elementary Forms of Religious Life" (1912). Within the sacred sphere, the most important values, imaginations and future options of a society are created and contained, and usually they are hidden from the everyday life of society because they

29 R. E. Parks, Human Migration and the Marginal Man, in: American Journal of Sociology 33, Issue 6, 1928, pp. 881-893, here p. 892.

30 Id., Introduction, in: E. Stonequist, The Marginal Man. A Study in Personality and Culture Conflict, New York 1937, pp. xvii-xviii.

31 M. Goldberg, A Qualification of the Marginal Man Theory, in: American Sociological Review 6, Issue 1, 1941, pp. 52-58.

32 V. Turner, Passages, Margins, and Poverty. Religious Symbols of Communitas, in: V. Turner, Dramas, Fields and Metaphors. Symbolic Action in Human Society (Symbol, Myth, and Ritual Series), Ithaca, NY [et al.] 1974, pp. 231-271, here p. 233 (also for what follows). 
are powerful and dangerous. Only through the means of a liminal figure who enters the sacred sphere for a limited time is it possible for the society to reconnect with and profit from the sphere of sacrality and thus to foster innovation, as Victor Turner argues. And as this liminar is able to return to the stable sphere of everyday life of the dominant culture, he can be of use to the constantly marginal.

More recently, the sociologist Bernhard Giesen has asserted that the foremost liminal figure who can enter this sacred space is the charismatic hero who has been assigned an ability by a group of admirers: the ability to enter into the dangerous sphere of the sacred imaginaire. ${ }^{33}$ This hands power to the heroic figures and makes them distinct and apart from everyday life. And this is one of the reasons, I argue, why the marginal intellectuals turned to the English warrior nobles in order to shape their heroic figures: These marginals were in need of some personal safety and stability, and thus in need of a liminar who was able to "draw away the dangers of in-betweenness" (Barbara Morehouse). ${ }^{34}$ They were able to fulfil this need, I argue, by connecting with the liminar through a state which Victor Turner has called communitas. It is, in Turner's view, the opposite of the "structure" of everyday life, mediated by common rituals: "The bonds of communitas are $[\ldots]$ undifferentiated, equalitarian, direct $[. .$.$] spontaneous, immedi-$ ate, concrete". 35

The marginals in the historical situation considered here thus could try to connect to heroic figures - figures they could, in turn, shape. The marginals were well advised to keep their one big advantage, their intellectual "objectivity", at all times, and therefore needed to retain their precarious social status. Thus, they could only temporarily join the communitas of the person embodying this heroised figure. By entering the communitas with this liminar, they could connect with the aristocratic would-be heroes and infuse them with their own conception of the hero, blowing the coals of their ambitions. And this meant that they could gain access to the sacred core of the host society, to reach the social imaginaire of the English society which shaped the scope of the political process. Thus, they could have a hand in the political decision-making process. This, of course, only holds true if one accepts that in the early modern era there continued to exist a form of sacrality. ${ }^{36}$ If the hero-makers had given up their marginal status, they would not have been able to offer the would-be hero, usually a sought-after and well-to-do aristo-

33 B. Giesen, Triumph and Trauma (The Yale Cultural Sociology Series), Boulder, CO/ London 2004, pp. 16-18.

34 B. Morehouse, Theoretical Approaches to Border Spaces and Identities, in: V. PavlakovichKochi [et al.] (eds.), Challenged Borderlands. Transcending Political and Cultural Boundaries, Aldershot 2004, pp. 19-39, here p. 31.

35 V. Turner, Metaphors of Anti-structure in Religious Culture, in: V. Turner, Dramas, Fields and Metaphors. Symbolic Action in Human Society (Symbol, Myth, and Ritual Series), Ithaca, NY [et al.] 1974, pp. 272-300, here p. 274.

36 Cf. C. Geertz, Centers, Kings, and Charisma. Reflections on the Symbolics of Power, in: J. Ben-David / T. N. Clark (eds.), Culture and Its Creators, Chicago 1977, pp. 150-171. 
crat, a great incentive to spend time and resources on them. As the heroised person became useful for the marginal hero-maker in this way, the hero-maker, in turn, was useful for the aristocrat, receiving help in his own self-heroisation in an innovative way. And the hero-maker was able to attach himself to the influential courtier figure so that his personal and mostly precarious fate would, in some way, become this aristocrat's business.

\subsection{Marginal Men Looking for Physical Safety}

Out of their misery and looking for hope, these marginals were "bound by the rules of safety", as Robert Naunton stated, to would-be heroic figures. In the view of the sociologist Hans Speier, any heroic figure is constructed as having "a healthy absence of anxiety"; he asserts that "the 'inner' security of the hero enables him to act" ${ }^{37}$ And for Speier, the hero's worshippers get to have "vicarious participation" in his deeds out of a desire for "transformation", as "a substitute for action from which they are barred by circumstance". 38 This is valid as well, I would argue, in this case, in which the intellectuals were barred from participating in aristocratic heroic behaviour such as fighting in a war - barred by their not being aristocratic, being too old or too bookish. In some ways, this restraint can turn into a privilege. As I will argue, the marginals needed to keep their status constantly on the verge, in a high-risk position. They could not simply turn into yet another usual client or they would have lost their position of enormous influence.

Languet did much to praise Sidney's sense of being safe himself, which in turn would make Languet feel safe, as in one letter to Sidney from 1 May 1574: "But, my noble Sidney, the only favour I ask of you is that you keep yourself safe and sound for my sake - this I earnestly beg of God, Who alone can grant it: as long as you are safe and sound, I shall consider all that is mine secure." ${ }^{39}$ And on $13 \mathrm{Au}-$ gust 1576, Languet praised Sidney's decision to return to England for his father's sake,

"but when I ponder those wild Welsh mountains, and that stormy Irish Sea, and almost everywhere the plague-ridden autumn, I am filled with anxiety for you. So by the love with which you have honoured me previously I beseech you that the minute you have come back to the safety and the delights of your Court you will let me know you are safe, and so free me from that care which (as the true poet says), burns and torments me, settled in my breast." 40

So for Languet it was essential - at least in his self-fashioning - to feel Sidney to be safe so that Languet himself could feel the same; and Sidney himself was likened by Languet to the fearless persons of arms of whom the Earl of Essex was to

37 Speier, Risk, Security, and Modern Hero Worship (footnote 18), p. 128.

38 Ibid., p. 133.

39 R. Kuin (ed.), The Correspondence of Philip Sidney, Vol. 1, Oxford 2012, p. 185.

40 Ibid., p. 701. 
speak in his Apologie (see above): Languet admired Sidney for "not fearfully avoiding the dangers and bothers of such a long journey" but, instead, embarking on such a dangerous trip solely, as Languet mentioned, for "filial piety". On yet another occasion, Languet confirmed this thinking (16 July 1578):

"I did think that love of mine for you deserved to be informed if you undertook something glorious but dangerous, so that I could solemnly beg God for your safety and wish you well. To this you might perhaps have replied that it was precisely because you know I am deeply concerned for you that you did not want to let me know what you had decided: there was danger involved, and you did not want the dangers you would have to enter into to torture me with fear and anxiety." 41

In this view, Languet confirmed that Sidney did involve himself in many a dangerous situation, but this was something the - obviously would-be heroic - Sidney did not fear at all; it was the Protestant father-figure, rather, who was filled with fear for his brave companion.

The second person under scrutiny here, Giordano Bruno, made his seeking protection by Sidney less explicit, although Bruno did have a "deep-seated need for economic and professional security" ${ }^{42}$ This need for personal safety can be traced in one longer passage. In the explanatory epistle to "The Expulsion of the Triumphant Beast" (1584), Bruno lets his own person talk - not, as usually in his work, veiled by a pseudonym: "Here Giordano speaks in a vulgar manner, freely designates"; and this free speech invokes "heroes" needed for his own well-being: "Come! Come! We see how this man" - he was still talking of himself - "as a citizen and servant of the world [...], because he loves the world too much, must be hated, censured, persecuted, and extinguished by it." Even though a certain literary persona is speaking here, in this bleak picture Bruno's own experience and existence serves as a foundation of feeling persectued, of being in fear of physical extinction. However, he does not simply wait for a bleak fate to happen: "But, in the meantime, may he not be idle or badly employed while awaiting his death". He turns to Sidney - in search of protection:

"Let him today present to Sidney [...] his moral philosophy [...], in order that he examine, consider, and judge them, accepting all that which must be accepted, [...] and defending all that which must be defended against the wrinkles and the brows of hypocrites, the teeth and the nose of the presumptuous, the file and the hiss of pedants." ${ }^{.43}$

These pedants - the famous Oxford scholars who refused to let Bruno develop his revolutionary ideas - were not only distracting or annoying; Bruno had stated this in the paragraph before, which I suggest needs to be read in conjunction with his fear for his physical existence because of his unheard of ways of thinking. Thus, in this dedication to Philip Sidney Bruno does show himself to be vulnerable to

41 Ibid., p. 849.

42 Imerti, Editor's Introduction (footnote 23), p. 7.

43 G. Bruno, The Expulsion of the Triumphant Beast, ed. and transl. A. D. Imerti, Lincoln, NE/London 1992, p. 72. 
threats from different publics, and he does turn to Sidney for "defending" him, in other words for personal safety against being threatened in his own existence. This can be underlined if one looks at the introductory chapter of the "Ash Wednesday Supper", in which Bruno embarks on dangerous "journeys and voyages, which will be judged by all to be more poetic, and perhaps allegorical, than historical" ${ }^{44}$ On his way, the English mob would "take every opportunity to imperil [Bruno's] life", ${ }^{45}$ and he would only find a safe haven in the house of Fulke Greville, Sidney's best friend, and their common group of aristocratic people who had invited Bruno to a - fictional yet allegorical - supper, "being welcomed graciously and seated ceremoniously at the table". ${ }^{6}$ "Sir Fulke" would say "that the Nolan had nothing to fear; the people he intended to invite were most mannerly and learned" ${ }^{47}$ On his way to this supper, Bruno, in the words of his literary alter ego "this heroic soul [...] in the midst of the misadventure of a sea of adversity", ${ }^{48}$ likens his allegorical struggles to a hero's journey: "Common and easy things are for vulgar and common people; men who are exceptional, heroic and divine pass along the road of difficulty". ${ }^{49}$ Helping in this "sea of adversity", Bruno found "these men who sit near the sun of the royal splendour", meaning mainly "the most illustrious and excellent knight, Sir Philip Sidney", whom Bruno assessed as "exceptional and singular" whilst juxtaposing him with "the bulk of the common people" of England; "they are such a stinkhole [...] in irreverence, incivility, coarseness, boorishness, savagery and ill-breeding". ${ }^{50}$ But yet, Bruno "arrived alive, by the grace of Heaven, at the port, id est, at the portal" of Fulke Greville's house. ${ }^{51}$

Quite similarly, Antonio Pérez thought himself to be in existential danger, even though he did not fear the English mob and academic pedants. For his prolonged stays in England within the household of Essex in the 1590s, a clear picture evolves: In 1571, Pérez had written to Catherine of Bourbon that he was seeking "somme haven where to save my person and to withdrawe it from this tempestuous sea", ${ }^{22}$ with which he referred to his constantly threatened life: As Pérez had been one of the main confidants of Philip II, the king tried everything so that Pérez would not spread his intimate knowledge, including death threats. So shortly before Pérez chose to seek Essex's help in England for a second time, he complained - as Edward Wilton, a member of Essex's staff recorded -, "that

44 Ibid., p. 69.

45 E. A. Gosselin, Introduction, in: G. Bruno, The Ash Wednesday Supper, ed. and transl. E. A. Gosselin, Toronto [et al.] 1995, pp. 11-53, here p. 39.

46 G. Bruno, The Ash Wednesday Supper, ed. and transl. E. A. Gosselin, Toronto [et al.] 1995, p. 69.

47 Ibid., p. 110.

48 Ibid., p. 119.

49 Ibid., p. 116.

50 Ibid., p. 120.

51 Ibid.

52 Ungerer, A Spaniard in Elizabethan England, Vol. 2 (footnote 1), p. 373. 
his intertaynement in Fraunce was not according to his expectation"; he feared "daungers threatened to his person" 53 and "could not with safety live in France". ${ }^{54}$ Instead, Essex was a "rock" to Pérez, his "fortress" and "firmamentum firmum" (cf. psalm 71). ${ }^{55} \mathrm{He}$ praised Essex in pseudo-Christian mystic language as his fixed point: "When you are not present, Mylorde, [my] soul wanders in search of you [...] so when you should be found, it should be able to rest in this, or in that, in one, or in another of your thousand virtues." ${ }^{56}$ In Gustav Ungerer's assessment, staying with Essex meant to Pérez "a haven, a retreat, offering protection and security". ${ }^{57}$

\section{Constructing Communitas - Constructing Heroes}

The following section will explore the different forms and media through which the three marginal men achieved communitas.

\subsection{Virtual Communitas: Languet, Sidney and their Circles}

The heroic figure of Philip Sidney was not without discrepancies. He embodied the fusion of the spheres of arma et litterae in one person, both being heroised at the same time in his "mixing and mingling" personal habitus. Thus, for Alan Sinfield, this bridging of cultural "faultlines" by Sidney's heroic persona described his "complex and unsatisfactory positioning [...] between the social worlds". ${ }^{8}$

Any interpretation of this heroic role needs to be founded in the correspondence between Languet and Sidney. Robert Stillman, a Sidney expert, finds it to be "the single most intimate and revealing body of correspondence" of any Renaissance writer. ${ }^{59}$ Béatrice Nicollier-de Weck, Languet's biographer, has meticulously traced and evaluated all 1057 surviving letters from Languet and has argued that in all of them, only for Sidney is there shown any personal sentiment at all. ${ }^{60}$ This communication between the "mentor" 61 and his disciple was polished by tropes and conventions of friendship and love from antiquity. This does

\footnotetext{
Ibid., p. 29.

Ibid., p. 31.

5 G. Ungerer, A Spaniard in Elizabethan England, Vol. 1 (Colección Támesis A; 27), London 1975, p. 403.

56 Id., A Spaniard in Elizabethan England, Vol. 2 (footnote 1), pp. 331-332.

57 Ibid., p. 17.

58 Sinfield, Faultlines (footnote 15), p. 89.

59 R. Stillman, Sir Philip Sidney and the Poetics of Renaissance Cosmopolitanism, Aldershot 2008, p. 14.

60 Nicollier-de Weck, Hubert Languet (footnote 19), p. 334. For the total number of letters, see ibid., p. XV.

61 R. Hillyer, Sir Philip Sidney, Cultural Icon, Basingstoke 2010, p. vii; H. R. Woudhuysen, Sir Philip Sidney and the Circulation of Manuscripts, 1558-1640, Oxford 1996, p. 215.
} 
not necessarily imply any sexual or homoerotic undertones, as Andrew Strycharski has pointed out. ${ }^{62}$ Rather, in Robert Stillman's words, Sidney received "the foundational assumptions of his intellectual life", ${ }^{63}$ of his "piety, politics, and poetics" ${ }^{64}$ As Roger Kuin states, it is the "relation to Languet" from which Sidney's life "took the impulse of [its] form" - which means that Languet was at the start of the Sidneian fashioning as a heroic figure. As Languet's position in Saxony had deteriorated since 1574, it was his hope to "pass the torch of the Reformed cause to Sidney", ${ }^{65}$ since he was seen by many in his circle as "Europe's best hope" 66 in their effort.

And it was this circle of Philippists, the followers of Philipp Melanchthon, which Languet tried to initiate Sidney into - by including him in its large epistolary network. This was not a usual form of creating community in a face-to-face society. As Languet never visited England in the time of the Sidney correspondence, there was no element of direct patronage or other forms of contact, such as common meals or lodging. And he certainly did not rely on Sidney's material help. Rather, he exerted an indirect influence from afar - moulded mainly by the content of these writings.

This becomes especially clear in a letter to Sidney from January 1574: "I am already reaping the sweet fruits of our friendship, because I see you loved by those whom I most wanted you to please." It is two members of his Protestant intellectual network who "praise you to the skies, congratulate themselves on your friendship, and thank me for having been as it were its matchmaker." This asserts that Sidney was being introduced to Languet's intellectual circle on the continent, but Languet saw to it that this was always connected to what Languet had in mind for Sidney:

"But make sure you respond to them with affection, and so save your reputation and mine; you need to satisfy good men's opinion of you, and be careful not to let the pleasure of praise so go to your head that you think you have already come to virtue's finishing-line, or that you have already sweated enough on that race-track where (on the contrary) you must train as long as you live - for it has no finishing-line but the end of a life lived for honour's sake. So you must go on, wherever your destiny calls you: whether happy or sad, it must be guided by virtue." ${ }^{67}$

62 A. Strycharski, Pedagogical Affect in the Early Sidney-Languet Correspondence, in: Sidney Journal 28, 2010, pp. 25-51.

63 Stillman, Sidney and the Poetics of Renaissance Cosmopolitanism (footnote 59), p. 15.

64 Id., Philip Sidney and the Catholics. The Turn from Confessionalism in Early Modern Studies, in: Modern Philology 112, Issue 1, 2014, pp. 97-129, here p. 115.

65 Id., Sidney and the Poetics of Renaissance Cosmopolitanism (footnote 59), p. 14. See also E. Berry, Hubert Languet and the "Making" of Philip Sidney, in: Studies in Philology 85, Issue 3, 1988, pp. 305-320, here p. 307.

66 Stillman, Sidney and the Catholics (footnote 64), pp. 106-107.

67 Kuin, The Correspondence of Philip Sidney (footnote 39), p. 84. 
In this way, Sidney was ordered rather than asked to sweat a little more and never to stop on his way to virtue - which Languet saw as the path for his wouldbe hero.

By means of letters like this one, Languet let Sidney enter into an already existing group, which I would call "virtual communitas". This term has been used to adapt Turner's thoughts for discussion of recent technological development, which takes away the necessity to physically get together in order to enter into communitas. ${ }^{68}$ But this concept of a virtual gathering bridging long distances was also utilized for the early modern form of long-distance contacts, the republic of letters, which was an important part of the intellectual networks of learned men and women, especially in the $17^{\text {th }}$ century and across regional and confessional borders. ${ }^{69}$ In addition, Mark Greengrass has spoken of "virtual communities" in relation to the confessional circles of intellectuals of that time in general. ${ }^{70}$

But it was not only the continental circle that was connecting in this way. Languet also showed great interest in Sidney's courtly faction and his surrounding circle in general. For instance, Languet took Philip's younger brother Robert Sidney under his protection when he was on his continental tour a few years after Philip. But Languet inscribed himself even further into Sidney's English circle of aristocrats. In another letter, he complains of not having received anything back from Sidney: "I rushed into those accusations seething with different emotions and quite disturbed for your sake". In this way, Languet used emotions to create a strong bond and to put pressure on Sidney - a way of connecting, if not without strains. Languet then goes on to explain his strong feelings thus:

\begin{abstract}
"My affection for you has grown to the point that not only am I fond of you, but for your sake of all those who for any reason are linked with you: and although your country was dear to me even before, as I had lived there for some time very pleasantly and experienced the kindness of many, now my love for it has grown so much that if I heard that something fortunate had happened to it I should be no less moved and delighted than if it concerned my own country."71
\end{abstract}

By connecting to Sidney in this intensive way, Languet developed an emotional bond that extended also to his country, making Languet something of a virtual compatriot, creating a temporary connection to "all those" who were "linked" to Sidney in a letter-based form of virtual communitas. As can be seen from

68 C. Helland, Online Religion/Religion Online and Virtual Communitas, in: J. K. Hadden / D. E. Cowan (eds.), Religion on the Internet. Research Prospects and Promises, London 2000, pp. 205-224.

69 C. T. Callisen / B. A. Adkins, The Old Face of "New" Social Networks. The Republic of Letters as a Virtual Community, Preprint, 2010, http://eprints.qut.edu.au/38406/, 10 June 2015.

70 M. Greengrass, Two Sixteenth-Century Religious Minorities and their Scribal Networks, in: H. Schilling / I. G. Tóth (eds.), Cultural Exchange in Early Modern Europe, Vol. 1, Religion and Cultural Exchange in Europe, 1400-1700, Cambridge 2006, pp. 317-337, here p. 337.

71 Kuin, The Correspondence of Philip Sidney (footnote 39), p. 41. 
Languet's phrasing, he connected the fate of the whole of England to the persons close to Sidney, and he did inscribe his own person into this circle - if only virtually through these letters. This reflects on the self-understanding of Languet's Philippist circle.

As Ernst Koch has shown, this confessional party did not try to gain a broad popular appeal (which the Lutheran Protestants often did) - rather, it was a bond of friends, an epistolary circle that was confident to be able to influence urgent political matters through intellectual elitism. ${ }^{72}$ Only through their avant-garde work, which would shut out the "multitude" of commoners, would it be possible to change the course of history.

\subsection{Dedicated Commensality: Bruno and the Sidney Circle}

As not many intimate letters from Bruno survive, I turn to his literary works published during his stay in England. His English period, lasting only 29 months, was one of the most productive for his printed output and was tied in many ways to the Sidney circle: I focus on the letters, dedicatory and explanatory, of his vernacular works, of which two were dedicated to Philip Sidney, namely "The Expulsion of the Triumphant Beast" and "The Heroic Frenzies". Another of them, the "Ash Wednesday Supper", deals with the Sidney circle directly. Its literary setting is the house of Philip Sidney's best friend Fulke Greville and describes a common meal shared by Bruno and the members of the Sidney circle (though Sidney himself is not mentioned as being present at this supper). As Wolfgang Leiner has put it, the dedicatory letter was a "weapon in the fight for securing a living", ${ }^{73}$ an art which flourished especially from about 1580 onwards in France and England. Those were, at the time, Bruno's countries of possible existence, and this way of seeking protection through dedication would continue to be used extremely often until a marked ebb two generations later ${ }^{74}$ - therefore, Bruno's way of relating to his possible benefactors was rather innovative at that time.

But Bruno was by no means a simple client deferentially seeking patronage from an aristocratic well-wisher. Bruno never lodged at a house of the Sidney circle. The 27 months he stayed in England from July 1583, he lived at the French embassador's residence in London, on whose largesse Bruno was "totally dependent"75 and to whom Bruno dedicated his first works printed in England.

72 E. Koch, Der kursächsische Philippismus und seine Krise in den 1560er und 1570er Jahren, in: H. Schilling (ed.), Die reformierte Konfessionalisierung, Gütersloh 1986, pp. 60-77, here p. 66, p. 68.

73 W. Leiner, Der Widmungsbrief in der französischen Literatur (1580-1715), Heidelberg 1965, p. 193.

74 Ibid., pp. 27-30, speaking mainly of France.

75 Imerti, Editor's Introduction (footnote 23), p. 7, p. 10. 
In the "Heroic Frenzies", Bruno's styling of Sidney as a hero becomes most apparent. In his dedicatory letter to him, he writes:

"These heroic matters may address a heroic and noble spirit, with which you are clearly endowed; these favours may be offered to so gracious a subject, and these honours to a lord so dignified, as you have always shown yourself to be. As for myself, I acknowledge that you have come forward with greater generosity than others." 76

Mentioning Sidney's generosity in heroising him actually sounds like seeking patronage. As John Bossy has argued: Bruno "began to socialise widely" after some months in London and he "must also have begun to think of writing for a new audience", 77 which was the courtly sphere of the Sidney circle. On the other hand, however, Bruno always made it clear that he had no intention to let his aristocratic counterparts dominate him. In the dedicatory epistle to the "Heroic Frenzies", Bruno vituperates Sidney - not very obscurely - for having written love sonnets to women ("Astrophil and Stella"). The whole enterprise of Bruno's "Frenzies", on the contrary, was to convince Sidney that the only worthy poetry was the one dedicated to the love of God and of the infinite worlds which he claimed to heroically find by intellectual means. Therefore, and not exactly charmingly, Bruno diminished Sidney's poems and English women in general as they did not deserve, in his mind, to be treated by poetry. It seemed like Bruno was biting the hand he was trying to be fed by. And in the "Expulsion of the Triumphant Beast" in particular, Bruno develops a telling image of himself. He was certain to be a member of "the true aristocracy" of the intellect and "was speaking on equal terms" to his dedicatee Sidney. ${ }^{78}$ Similarly, in the "Heroic Frenzies" Bruno styles himself "il furioso": ${ }^{79}$ In doing so, he refers to himself as all but a hero, putting himself on the same heroic level as Sidney, to whom the work is dedicated.

I will now turn to the "Ash Wednesday Supper" as the literary allegory of forming communitas with the Sidney circle. At the suppers of English courtiers, which Bruno in fact attended and which provided the model for his fictional "Ash Wednesday Supper", Sidney was in all probability present. ${ }^{80}$ The commensality described by Bruno is not only reminiscent of Plato's "Symposion" but also links two important rituals: the end of carnival, the time of the year in which all worldly order is turned upside down, and the beginning of Lent as a time of spiritual askesis. ${ }^{81}$ As Victor Turner has stated, commensality could be a means of communitas,

76 G. Bruno, On the Heroic Frenzies, ed. E. Canone, transl. I. D. Rowland, Toronto [et al.] 2013, p. 31.

77 J. Bossy, Giordano Bruno and the Embassy Affair, New Haven, CT [et al.] 1991, p. 24.

78 von Koppenfels, Ash Wednesday in Westminster (footnote 26), p. 73.

79 S. Roush, Hermes' Lyre. Italian Poetic Self-Commentary from Dante to Tommaso Campanella, Toronto [et al.] 2002, p. 124.

80 N. Ordine, Introduction, in: G. Bruno, Expulsion de la bête triomphante, Vol. 1, ed. G. Aquilecchia, transl. J. Balsamo (Euvres complètes de Giordano Bruno; 5), Paris 1999, p. CLXVI.

81 See A. Eusterschulte, Giordano Bruno zur Einführung, Hamburg 1997, p. 16. 
especially in such a ritualised form. ${ }^{82}$ And Bruno states in this work that "the nobility of humankind [...] is shown by those virile, courageous and intrepid people who will never be divided among themselves". ${ }^{83}$ The meal Bruno describes in order to show his union with the aristocratic courtly sphere in London was rather a disaster. Bruno describes the confusion of ranks that immediately preceded the ultimately unsuccessful - communion ritual, the passing of the cup. This ceremony, as described above, went horribly wrong and was ridiculed by Bruno. And even though Bruno describes open arguing at the supper table, to the point of breaking the whole conversation down, this does not necessarily mean dissolution of this communitas. On the contrary, he evokes the raw, violent energy of an antagonistic culture, I assume, in which through confrontation the most intense form of human interaction and exchange takes place, as Georg Simmel has remarked in his seminal essay "The Conflict" ("Der Streit", 1908 ${ }^{84}$ ). The way the truth reveals itself in Bruno's writings is agonistic - it "unfolds", in Sherry Roush's assessment of his dialogues, "in the play of countering positions". 85

Even though it is not clear how much influence Bruno really exerted on Sidney, most scholars agree that Sidney's circle was familiar with him and his teachings. Bruno's works were, even if heretical and potentially dangerous (and often snatched away by the authorities), circulating among Sidney's circle - at least Arthur D. Imerti believes this "reasonable to assume". ${ }^{86}$ Arnolfo Ferruolo calls the intellectual worlds of Bruno and Sidney "molto vicino" and certifies them as "una simile esperienzia spirituale". ${ }^{87}$ And even if Bruno's direct influence on Sidney cannot be ascertained by the surviving evidence, his writings left a mark on the intellectual grounds of Sidney's circle, as will be shown in the conclusion.

\subsection{Theatrical Co-Residence: Pérez and the Essex Circle}

The question of whether the marginal men were simply seeking patronage is most obvious in the case of Antonio Pérez. His interaction with Essex and his circle can be interpreted mainly from his letters, in which Essex plays a role from 1593 to 1599 . There were some intimate letters, but most of them were written for publication, as were most of the other documents by the other two marginals already considered: Once, Pérez bragged that the demand for his Spanish letters

82 Cf. V. Turner, Pilgrimages as Social Processes, in: V. Turner, Drama, Fields and Metaphors. Symbolic Action in Human Society, Ithaca, NY [et al.] 1974, pp. 166-230, here p. 205.

83 G. Simmel, Soziologie. Untersuchungen über die Formen der Vergesellschaftung (Gesamtausgabe Georg Simmel; 11), Frankfurt am Main 1992, p. 284.

85 Roush, Hermes' Lyre (footnote 79), p. 11.

86 Imerti, Editor's Introduction (footnote 23), p. 21.

87 A. Ferruolo, Sir Philip Sidney e Giordano Bruno, in: Convivium 5, 1948, pp. 689-699, here p. 699, p. 697. 
was such "that they were virtually snatched from his hands". ${ }^{88} \mathrm{He}$ was an "epistolomaniac" who wrote letters for "recreatio animi" - Gustav Ungerer sees his extensive use of different styles as a testimony that Pérez conceived of himself to be "a member of the Republic of Letters". 89

At first glance, the image of the totally dependent client is a convincing one, since Pérez actually lived in the earl's household from March 1594 to July 1595 and was dependent on his monthly allowances of 20 pounds plus other expenses ${ }^{90}$ for as long as he stayed in England, thus closely resembling just any other dependent client. ${ }^{91}$ In what follows, I will show that their relation cannot be classified that easily: There were many elements of distance left that could produce an unstable, liminal status of communitas between the hero-maker Pérez and the heroic figure Essex.

Although living in the household, Pérez never fully integrated himself into the circle. For instance, in this Protestant surrounding of Essex House, he was allowed to practice the Catholic "religion of his fathers and forefathers, with a thousand personal favours". ${ }^{92}$ And whilst lodging there, Pérez lived in the rooms that afterwards were to be inhabited by Anthony Bacon, the earl's secretary, who "was a 'special friend" and "maintain[ed] this distinction" to the earl's clients. After Bacon, the same apartment came to be used by Robert Sidney, Philip's less well-to-do, but aristocratic surviving brother, which also suggests that Pérez was on equal terms with the aristocratic elite. ${ }^{93}$

Still, and contrary to Bruno, Pérez styled his relation to the heroic figure as totally deferential. Whilst Pérez usually oscillated between "megalomania" and "servilism", ${ }^{4}$ in relation to Essex he always chose the second option. I would even argue that these seemingly so insincere traits were a conscious art of exaggeration: By doing so, he disclosed that this was actually a play, a big theatrical façade. This also fits the extreme largesse that Essex showed toward Pérez: As Paul Hammer notes, the exuberant lifestyle Essex allowed Pérez, especially the splendid and ruinously expensive presents he made to him, not only managed to instill envy and maybe even an element of competition among his followers; it was also an important part of maintaining a distance from the household and

88 Ungerer, A Spaniard in Elizabethan England, Vol. 1 (footnote 55), p. 72.

89 Id., A Spaniard in Elizabethan England, Vol. 2 (footnote 1), pp. 362-363.

90 P. Hammer, The Polarisation of Elizabethan Politics. The Political Career of Robert Devereux, $2^{\text {nd }}$ Earl of Essex, 1585-1597, Cambridge 1999, p. 132.

91 This is Alexandra Gajda's assessment, see A. Gajda, The Earl of Essex and Late Elizabethan Political Culture, Oxford 2012, p. 10.

92 Ungerer, A Spaniard in Elizabethan England, Vol. 1 (footnote 55), p. 145, transl. mine.

93 P. Hammer, The Uses of Scholarship. The Secretariat of Robert Devereux, Second Earl of Essex, c. 1585-1601, in: English Historical Review 109, 1994, pp. 26-51, here p. 35, esp. n. 6 .

94 Ungerer, A Spaniard in Elizabethan England, Vol. 1 (footnote 55), p. 76, calls this a "telescopic view". 
clients of the earl - as Marcel Mauss has shown in his seminal work "The Gift", this agonistic form of giving, always having to transcend the extremes beforehand, is a tool to connect to and, at the same time, control one's counterpart: ${ }^{95}$ Had Pérez been just a client, this would not have been necessary.

Fittingly, Pérez was seen increasingly often with suspicion and sometimes outright hostility by other members of the circle. ${ }^{96}$ For example, Anne Bacon wrote to her son Anthony, the trusted secretary of the Earl of Essex: "I wold you were well ridd of that olde, dooted [stupid] [...] papist", ${ }^{7}$ "that Bloody Peerez [...] a prowde, prophane, costly fellow", 98 as she stated on another occasion. Even though Pérez probably did not do much to earn the trust of the other members of the circle, this deep dislike seems to have something to do with Pérez's status as an extraordinary figure, always detached from the other members.

This group - of which Pérez was a part, though a rather awkward one - installed around the heroic figure of Essex, the "Maecenas", ${ }^{99}$ and within his household a "vigorous learning programme", 100 as Essex was "a trusting product of his educational environment" ${ }^{101}$ This programme created, in Rory Rapple's words, a "mental world, a net that caught so much of the intellectual richness of its time". ${ }^{102}$ Pérez was an important part of the "brain trust" 103 that shaped the earl's imagery. Although many of the heroic motives and narratives of this group had already been established, Pérez did much to broaden and re-fashion the rhetorics with which Essex was being adulated.

To do so, Pérez could draw on his reputation as the "leading Tacitean scholar in Spain". ${ }^{104}$ Because of that, others in the Essex circle who were Taciticts in the mould of Justus Lipsius were willing to listen to Antonio Pérez. I do not agree with Gustav Ungerer's assessment that it was merely a "stroke of luck" 105 for him to find this body of intellectual resonance, for Pérez actually could infuse them

95 S. Moebius, Die sozialen Funktionen des Sakralen. Marcel Mauss und das Collège de Sociologie, in: Revue du Mauss permanente, 16 March 2008, http://www.journaldumauss. net/spip.php?article301, 10 June 2015

96 Hammer, The Polarisation of Elizabethan Politics (footnote 90), p. 357. He ascribes this to Pérez's "profound personal insecurities".

97 Ungerer, A Spaniard in Elizabethan England, Vol. 1 (footnote 55), p. 221.

98 Ibid., p. 219.

99 A. Hiscock, "Achilles alter". The Heroic Lives and Afterlives of Robert Devereux, $2^{\text {nd }}$ Earl of Essex, in: A. Connolly / L. Hopkins (eds.), Essex. The Cultural Impact of an Elizabethan Courtier, Manchester/New York 2013, pp. 101-132, here p. 111.

100 Ibid., p. 108.

101 Gajda, The Earl of Essex and Late Elizabethan Political Culture (footnote 91), p. 256.

102 R. Rapple, Review of A. Gajda, The Earl of Essex and Late Elizabethan Political Culture, Oxford 2012, in: The Journal of Modern History 86, Issue 3, 2014, pp. 664-666, here p. 666.

103 Ibid., p. 665.

104 Ungerer, A Spaniard in Elizabethan England, Vol. 2 (footnote 1), p. 371.

105 Ibid. 
even more - could blow the coals of Tacitism in this circle rather than just going along with the tide. In this way, Pérez was helping the "Tacitean explosion"106 of the 1590 s to take intellectual shape.

His heroisation strategy was, even more importantly, a "decisive step in the deification" of Essex (Ungerer): The most conspicuous thing Pérez added to the aristocrats' heroisation was "Christian content" such as imagery from the Bible.107 Ungerer has called this biblical style "adulating incense, whose perfume must temporarily have ravished the senses of the Essexians". ${ }^{108}$ For instance, as Robert Naunton points out, Pérez boasted in 1597 that he had "aequelled" Essex "alone of all Men liuing with God himselfe", and he did so in a "straunge voice" which was as yet unheard of in England. 109

But this extreme reversal of hierarchies was not only blasphemous but also potentially subversive against the social order. And it was not a sincere expression of a simple reality but was overtly artificial. Pérez and Essex saw this, as Gustav Ungerer argues, "as a literary and social game". ${ }^{110}$ Pérez is viewed by Robert Naunton as a shape-shifter, a Proteus, "who, before a man can pourtray him all at length in any one likenes, will still transforme himselfe into another". ${ }^{111}$ This playful interaction, I argue, was a means of bridging social and cultural gaps - of creating a special form of communitas. ${ }^{112}$ Essex sanctified Pérez, calling him "o te beatum", whom Essex had received in a form of asylum: "in tale te asylum recepisti". Unlike Gustav Ungerer, ${ }^{113}$ I believe that this was not simply a business exchange between patron and client.

The mystic union Pérez forged between himself and Essex - "non ego in me, sed in te viuo"114 - did serve a purpose: It tied the Earl of Essex to Pérez, as he conformed to Pérez's stylization. This hints at something else: Pérez's fine rhetorical distinctions for different audiences. He might have helped Essex develop his articulate and distinctive style of varying his means for his respective publics. As he was much more involved in courtly politics and foreign policy than Sidney, he used his pen rather sensitively; his "politics of popularity", appealing to some of

\footnotetext{
106 B. J. Irish, The Literary Afterlife of the Essex Circle, in: Modern Philology 112, Issue 1, 2014, pp. 271-285, here p. 277, with reference to the vast literature on the topic in n. 27.

107 Ungerer, A Spaniard in Elizabethan England, Vol. 2 (footnote 1), p. 366.

108 Ibid., p. 367.

109 Ibid., pp. 130-134.

110 Ibid., p. 370.

111 Ibid., pp. 130-131.

112 To explore this further, see B. Giesen, Performing the Sacred. A Durkheimian Perspective on the Performative Turn in the Social Sciences, in: J. C. Alexander [et al.] (eds.), Social Performance. Symbolic Action, Cultural Pragmatics, and Ritual, Cambridge 2006, pp. 325-367.

113 Ungerer, A Spaniard in Elizabethan England, Vol. 2 (footnote 1), p. 369: "In return for his worship he expected patronage."

114 Ibid., p. 370.
} 
the urban and military masses, ${ }^{115}$ went hand in hand with an instrumental use of courtly articulations like poems and highly styled letters to the Queen. Hence, I would argue that in competitively creating this all-too transparently artificial glasshouse of blasphemous adulation with Pérez, he used him as an intellectual sparring partner, a partner in heroification, challenging and re-writing a heroic code. This fashioning gave the relation between Essex and Pérez a theatrical mode, an air of dissimulation which, in turn, gave Pérez, I would argue, the freedom to act not as a mere household companion but as a figure that kept enough distance to heroise and be heroised himself. Thus, both sides profited from Pérez staying on the margin and behind the threshold, never fully integrating into the Essex circle.

All three marginals, in their very different ways and means to form a communitas with the heroised aristocratic figure, never quite gave up their distance from the heroised figure and the social circle surrounding it. Be it the physical distance of writing letters, be it the literary creation of a failed commensality, be it the pompous deference with all the obvious artificiality and dissimulation, this might have served to distance the potentially dangerous business of heroisation - always beyond the threshold of everyday life routines - from daily business.

Yet still, with all this distancing, there emerged the possibility for the marginal men to gain acceptance in the Sidney-Essex circle and become part of a group of transcultural intellectuals. It is possible to detect and to pinpoint the free-floating intelligence of the Renaissance go-betweens here, of the third space of opportunity and imagination shared by the marginal men with the courtiers and their circle. At the same time, there is a clear exclusion of the "multitude", of common people not deemed worthy or able to partake in this important task: to challenge and influence the "sacred core" of late Elizabethan English society. In the following section, I will trace its contents.

\section{Hope for Political Safety: Marginals and the Military}

What did the marginals hope for in a larger sense in connecting with these English courtly warriors, besides their physical safety? By thus connecting with English society, I will argue, these intellectuals turned from their "misery" to the "hope" of a political agenda. They tried to shape the direction and the outcomes of European politics on a grand stage.

And in fact, Philip Sidney was seen by many continental Protestants as the "best hope" for their fate. And the Earl of Essex stated that "pubelique safetie"116 was the main goal that must be striven for. He wrote this in his "Apologie" in 1598 , in which he defends - at the height of his fame as a military leader - his

115 P. Hammer, The Smiling Crocodile. The Earl of Essex and Late Elizabethan Popularity, in: P. Lake / S. Pincus (eds.), The Politics of the Public Sphere in Early Modern England, Manchester 2007, pp. 95-115.

116 R. Devereux, 2nd Earl of Essex, An Apologie, London 1598, p. C2 verso. 
urging for a war against Spain. And Essex considered himself to be one of those martial men of the Elizabethan regime who were in charge of this safety. In which way the thoughts of the hero-makers aligned with this kind of thinking will be traced in this last chapter.

The aforementioned political safety should not be confused with another concept that has engaged early modern historians in the past few years but which, for the groups I am interested in here, had taken on a different meaning: the term "security". ${ }^{117}$ For instance, in 1577, Amias Paulet, one of the "forward Protestants", wrote the following assessment of England's present peacefulness: "We are bold enough to fear nothing when the peril is most imminent, [but] we are fearful and afraid of a very shadow where things are most easy. These be the fruits of security." $118 \mathrm{He}$ meant that in peace, under the surface of stability, no actual safety was achieved. As Blair Worden has shown, this "false" sense of security was a widely used term in the circle which promoted a militant, aggressive foreign policy and which prominently featured Sidney and later Essex. Such an illusion was set against a sense of real security that warrior nobles had when "the peril" was "imminent": This is very similar to what Hans Speier has seen as the core of being a hero. So, if this "false" sense of security was not what the forward Protestants were hoping for, what were the hero-makers' aspirations in a larger, political sense?

\subsection{Languet's Politics of Steering Sidney}

It was in key political moments between England and France that the connections between the hero-makers and the heroised were shaped: Philip Sidney probably got to know Hubert Languet at the English embassy in Paris when both were trying to hide from the Catholic prosecutions of St Bartholomew's Night in 1572, which shattered the last hope of the Huguenot Languet for his native France to return to an ecumenical path. With Queen Elizabeth being called a heretic in a papal bull in 1570 and the Ridolfi Plot in 1571, England had turned to a more aggressive and, for the first time, relatively consistent foreign policy on the basis of confessional matters. ${ }^{119}$ Languet's extended correspondence with Sidney culminated at the time of the French match, the wooing of Queen Elizabeth by the French king's younger brother, which came closest to success in 1579, shortly before Languet's death. Languet began courting Sidney with special

117 For the growing importance of the concept security in early modern studies, see, by means of example, Q. Skinner, Liberty and Security. The Early-Modern English Debate, in: C. Kampmann / U. Niggemann (eds.), Sicherheit in der Frühen Neuzeit. Norm - Praxis Repräsentation, Köln [et al.] 2013, pp. 30-42.

118 B. Worden, The Sound of Virtue. Philip Sidney's "Arcadia" and Elizabethan Politics, New Haven, CT/London 1996, p. 202.

119 Ibid., pp. 71-88. 
intensity in May 1574, when his circle of Philippists was thrown out of favour in Saxony because the elector was suspicious of them being crypto-Calvinists - a state of panic when his elitist, intellectual circle was on the brink of losing any influence in the political scene. Thus, courting Philip Sidney in this way actually opened up a new political perspective: getting England on board with the Philippist movement. Their aim was to eventually reunify the emerging confessions and militarily fight the perceived enemies of a peaceful reunified Europe which were Spain and Rome. At this time, even the emperor was still allowing for debate and for possible reconciliation between the confessions; when he died in 1577, this did indeed alter the course of actions, especially in this group. ${ }^{120}$ Languet's cause was getting more and more desparate and calling for immediate, aggressive action, as can be traced in his correspondence with Sidney, especially after Languet had started residing in Cologne in 1577 to be close to William of Orange. In some of the following, he urges for military help from England in the Netherlands directly.

"I am going to be frank with you", Languet writes in one of the main instances in which his political agenda shines through in his stylised correspondence with Sidney,

"I thought the practices of your court less manly than I could have wished: I got the impression that most of your noblemen are looking for praise rather for their stylized affability than from those virtues that are good for the commonweal and most suitable for noble minds and high-born men. So was I sad (and so were your other friends) to see you wasting the flower of your years on such things."

And Languet continues, invoking Sidney's father and family members:

\begin{abstract}
"You would respect their authority in absence [that is, if Sidney would travel to the continent as Languet wished] if you devoted yourself to the military, and even more so if you had some successes in it. For if you diligently cultivate those remarkable seeds of virtue God has planted in your spirit, and acquire experience in warfare and authority among soldiers [...], think how useful and what a protection you could be to your country in precarious circumstances; and your country will certainly need men of no common virtue to avert the ills that appear to loom over it."121
\end{abstract}

Here, Languet formulates what he obviously wanted Philip Sidney to become: a military leader who would defend England on the continent, saving it from dangers which clearly stemmed from Spain and from the Catholic powers. This "protection" Languet talked of was of course not meant as help only for England but also for Languet, who tried to make his English allies think his own way by using and steering Sidney as a would-be heroic figure, moulded for success on the battlefield.

120 On the importance of the ecumenical court of Maximilian II in Vienna for Sidney, see Stillman, Sidney and the Poetics of Renaissance Cosmopolitanism (footnote 59), pp. 205-206.

121 Kuin, The Correspondence of Philip Sidney (footnote 39), pp. 931-932. 
This challenge did not go unnoticed. In the intellectual sphere as well, Sidney brought up military means. On 1 March 1578, Sidney asked Languet to "call me back" from "elegantly playing the Stoic" and "Cynic" at court, ${ }^{122}$ meaning that he wanted Languet to exercise his wits instead of letting him succumb to the decadence of court society: "Get ready to set upon me: I have now indicated the battlefield, and openly declare war upon you." 123 Thereby, Sidney likened the intellectual challenge to the military sphere; the longed-for combatting of the minds was a war to be fought. On both sides, the military and the intellectual endeavour "mixed and mingled". 124

In July 1578, Languet directed his military ambition by invoking his own aged and pacifist self: "The only reason I want God to prolong this calamitous old age is that I may see you in your absolute glory, and your virtue set in such a noble place that you will have no choice but to pursue those things that procure for men immortal fame. So now you must set out upon that road: for you there is no retreat open that is not accompanied by shame." $125 \mathrm{He}$ thus appealed to Sidney's sense of honour to set him on the track for "immortal fame" which, in this instance and background, could only mean pursuing a career on the battlefield.

These passages prove those wrong who have asserted that Languet mainly tried to tame the "savage beast" in the aristocratic would-be warrior Sidney.126 Sidney was by no means tamed, but he was infused with virtue and reliablity, which made him to some degree controllable.

What Languet actually achieved by fostering Sidney's military ambitions is not certain. Long thought to be the foremost "forward Protestant", 127 Sidney was, in Stillman's view, "resist[ing] easy confessional identification", ${ }^{128}$ not being a crypto-Catholic, as Katherine Duncan-Jones believes, either. But still, his political agenda was one of constant pushing for aggressive military intervention on behalf of his religious cause, no matter which faction or inner belief system he adhered to. And Languet was not the only person trying to blow the coals of Sidney's warrior ambition, but he was certainly instrumental in creating the military persona

122 This passage recently lent the title to a whole article, see Wood, "Cleverly playing the Stoic" (footnote 13), pp. 25-46.

123 Kuin, The Correspondence of Philip Sidney (footnote 39), p. 817.

124 Gavin Alexander sees "mixing and mingling" as the most important aspect of Sidney's literary work, G. Alexander, Sir Philip Sidney's Arcadia, in: A. Hadfield (ed.), The Oxford Handbook of English Prose, 1500-1640, Oxford 2013, pp. 219-234, here p. 225.

125 Kuin, The Correspondence of Philip Sidney (footnote 39), p. 850.

126 Cf. R. Headlam-Wells, Shakespeare on Masculinity, Cambridge 2000, p. 17: Languet as being "typical of those humanists who had reservations about the culture of violence fostered by militant Protestantism". R. Manning, Swordsmen. The Martial Ethos in the Three Kingdoms, Oxford 2003, p. 55, p. 66, cites only the irenic-sounding passages of the LanguetSidney letters.

127 Worden, The Sound of Virtue (footnote 118), pp. 76-88; R. Howell, The Sidney Circle and the Protestant Cause in Elizabethan Foreign Policy, in: Renaissance and Modern Studies 19, 1975, pp. 31-46.

128 Stillman, Sidney and the Catholics (footnote 64), pp. 97-129. 
Sidney would embrace. This finding is in accordance with what Beatrice Nicollierde Weck has shown about the Philippist circle surrounding Languet to be "l'étrange contradiction" between "irénisme" and the urge to work militantly towards the victory of Reformation, "de triompher ou de périr". ${ }^{129}$ But it is not only Languet who has been misunderstood profoundly as being nothing but irenic.

\subsection{Bruno Shaping Sidney and the Anglo-French Compromise}

The rediscovery of Giordano Bruno was led by the eminent British cultural historian Frances Yates. Although many of her assumptions will in all probability remain dubious because they cannot be proven by any of the remaining sources, I would like to return to her focus in looking at Bruno's texts. She believed that Bruno's aim in his Italian dialogues was actually political, but profoundly irenic: to bring together the aristocratic elites of England and France in an endeavour to reconcile both countries in one single Christian faith, thus ending the religious wars and rebellions spread across Europe. In Bruno's view, this was all connected to the sickening influence of the militantly Catholic Spanish crown. Edward A. Gosselin has maintained recently that Bruno's "Ash Wednesday Supper" serves this highly political purpose: namely, that of trying to unite the courtiers of London with those of Paris, thus bringing England and France into a political union in this form of a Eucharist celebrated together at the house of Sidney's closest friend, Fulke Greville. ${ }^{130}$

After some stable years for Bruno at the French court and in its glamorous surroundings, ${ }^{131}$ trouble was on its way. England and France likewise were threatened by Spain when Bruno travelled to England with the French ambassador de Castelnau, who would entertain Bruno in his London household for the time of his stay. In these months, the French king Henri III came under attack in a bloody continuation of the religious wars against the Catholic League, a radical aristocratic faction led by the Guise. ${ }^{132}$ France was briefly on amiable terms with England, reaching out in the face of the common Spanish threat. ${ }^{133}$ But by July 1585 , Henri III had to agree to a humiliating contract with the League, and soon after, the French envoy de Mauvissière left London for good, taking Bruno with him - their diplomatic efforts were not needed anymore. As Edward A. Gosselin

129 Nicollier-de Weck, Hubert Languet (footnote 19), p. 463.

130 Gosselin, Introduction (footnote 45), p. 40, p. 49.

131 Imerti, Editor's Introduction (footnote 23), pp. 6-7.

132 R. Kohlndorfer-Fries, Diplomatie und Gelehrtenrepublik. Die Kontakte des französischen Gesandten Jacques Bongars (1554-1612), Tübingen 2009, p. 237.

133 Gosselin, Introduction (footnote 45), p. 52: In June 1584, the heir to the French throne, Henri III's younger brother, died and left the Protestant Henri de Navarre as heir; Elizabeth let Henri III enter into the Order of the Garter; a "fragile" moment, but one of opening up opportunities, a "flirtation between France and England". 
notes, "Bruno's thinking was tied to the political and religious squabbles of the time", ${ }^{134}$ and it needs to be viewed in this context.

For instance, in Bruno's "Ash Wednesday Supper”, his alter ego, Teofilo, talks about Elizabeth's "most illlustrious and excellent knights", "even if I do not personally know them":

"These men who sit near the sun of the royal splendor are able, with the light of their lofty culture, to expunge and dispel the darkness [...] and to smooth and polish any rudeness and crudity [...]. You cannot properly describe the polite conversation, the kindness and politeness of the many knights [...] of the realm. Among them is the most illustrious and excellent knight, Sir Philip Sidney, who is so well known [...]. His totally unblemished character and his most praiseworthy manners make him so exceptional and singular [this being one of the prerequisites of the hero, being out of the ordinary] that it is difficult to find his like [...] either outside or inside Italy.”

Bruno continues by positing the exact opposite against this shining ideal: "The bulk of the common people presents itself most importunately before my eyes; they are such a stinkhole that, if they were not mightily well suppressed [...], they would [...] darken the name of the whole population [of England]."135 Thus, Bruno was arguing for Sidney's and his group's help against all kinds of common people. But this was not the only enemy Bruno feared and seeked protection against.

Whilst the tone against the enemy, the King of Spain, was not as aggresive as Languet's, a "notable anti-Spanish bias" can be found in the entire "Expulsion of the Triumphant Beast". It contains a "fervent plea for a new moral and political order in Europe" (Werner von Koppenfels). ${ }^{136}$ Thus, in one passage Bruno turns against those "working with the pretext of wanting to preserve [false] Religion", a remark clearly, as Arthur D. Imerti notes, aimed at intolerant Catholic Spain. This was "inexcusable" for Bruno: "For protection or care is not required where no ruin or peril threatens, where minds are exactly the same as they were." 137 In this view, the Spanish oppression, the impending "changing of the minds", was threatening Europe's ruin, against which "protection or care" was necessary. Though without a direct call to arms, this must be read as a veiled, but intense cry for militant action against Spain. Nuccio Ordine interprets the dedication of the "Expulsion of the Triumphant Beast" to Philip Sidney as a demand "to assist him" - Bruno - "in the battle". 138 Whilst Bruno's eventual aim may really be called "irenic", ${ }^{139}$ it was to be achieved by military or, at least, militantly aggressive means.

134 Gosselin, Introduction (footnote 45), pp. 52-53.

135 Bruno, The Ash Wednesday Supper (footnote 46), pp. 119-120.

136 von Koppenfels, Ash Wednesday in Westminster (footnote 26), p. 73.

137 Bruno, The Expulsion of the Triumphant Beast (footnote 43), p. 196. See commentary on p. 302 for the reference to Spain.

138 Ordine, Introduction (footnote 80), p. CLXII: “de le soutenir dans la bataille”.

139 Gosselin, Introduction (footnote 45), p. 37. 


\subsection{Pérez Fashioning Essex and the Fight Against the Common Enemy}

Whilst the military element was not overly prominent in Giordano Bruno's writings, ten years later, Antonio Pérez saw to it that a propagandistic, artificial style of boosting military ambition developed in Essex's circle.

Pérez came to England in another key moment of Anglo-French relations. In the mid-1590s, the Spanish threat became manifest again. King Henri IV converted to Catholicism in 1593, casting doubts among the continental Protestants, who looked to him as a potential figurehead, but also testing the relations with the Essex circle, with whom Henri had entertained a cordial bond. Despite Henri's conversion, the Spanish crown did not ease its involvement in the French religious wars until 1598, and this perceived threat continued to hold sway in the English courtiers' imagination as well, as the capture of Cádiz by the Earl of Essex in 1596 makes obvious. When Pérez came to England in mid 1593, he did so in a "crucial" 140 year in Essex's political career: He was appointed to the Queen's Privy Council, and he was just starting "the casting of secret intelligence" networks which would hand Essex a pivotal role in English foreign policy, at least for a while. The excellent contacts Pérez had on the continent helped him instantaneously to gain the earl's trust and ear. ${ }^{141}$

And soon, as William Camden wrote, Essex made "vse of him (as an Oracle) that was so well skilled in the secrets of the Spanish Court, and that was a man of excellent wit and wisdom, who notwithstanding (as most commonly such kind of men alwaies are) was so tossed vp and down by fortune". ${ }^{142}$ Here again, the precarious situation of the marginal intellectual is evoked. Pérez used his "wit and wisdom" in an extremely partisan fashion, giving the circle's foreign policy direction and drive. When the Earl of Essex had just achieved his greatest military victory, the capture of the Spanish port of Cádiz in August 1596, Pérez could barely contain his vengefulness: "Mylord, persecute, my Lord, the tyrant, persecute the tyrant! [...] Plus ultra, my Lord! Large are these, larger but remain things for you [to be done]." And Pérez continued stirring the earl to further action, going even as far as imploring Essex to kill the Spanish king. ${ }^{143}$ In Pérez's letters, Philip II features variously as "Nebuchadnezzar", "Nero", "Pharaoh" or simply "Tyrannus". ${ }^{144}$

Alexandra Gajda assesses Pérez as attaching "himself passionately to the earl's rising star, seeing in Essex the man who could bring Spanish power to its knees". What Pérez had in mind was, as Gustav Ungerer has summarised, "an alliance of all the enemies of Spain, a League embracing Christians as well as Muslims". ${ }^{145}$ It

140 Ungerer, A Spaniard in Elizabethan England, Vol. 2 (footnote 1), pp. 168-169.

${ }^{141}$ Hammer, The Polarisation of Elizabethan Politics (footnote 90), pp. 180-181.

142 W. Camden, Annales, Vol. X, London 1625, p. 106.

143 Ungerer, A Spaniard in Elizabethan England, Vol. 1 (footnote 55), pp. 444-445, transl. mine.

144 Id., A Spaniard in Elizabethan England, Vol. 2 (footnote 1), p. 438.

145 Id., A Spaniard in Elizabethan England, Vol. 1 (footnote 55), p. 73. 
was especially Pérez's "writings on kingship and tyranny", not least in his Tacitean ideology, that "had a deeper significance in shaping political discussions". ${ }^{146}$ Although the Earl of Essex and his courtly faction had shaped the outlines of their aggressive foreign policy before Pérez set foot on English soil, the elaborate rhetoric and urgency which Essex employed in his "Apologie" in 1598 was probably indebted to Pérez's mastery and advice on content and style: "Now, now is the fittest time to make warre vpon the Spaniard", because: "Now it is no time to make peace with the chiefe enimy of our religion." 147

So what was the underlying principle these three marginal hero-makers had in common in trying to influence the political sphere of their host country? The sociologist Hartmut Esser has pointed out that hero-worship has its root in the fact that the hero is willing to sacrifice himself for the group - he takes the first, risky step and thus makes it easier for others to follow him. Willing to sacrifice himself for the group and thus to stimulate the group morally to follow, the hero therefore resolves the problem of collective apathy. ${ }^{148}$ Following this, I would turn Camden's assessment upside down: It was not only the social group surrounding the heroised person who would inflate this person to larger-than-life measures by "blowing the coals of his ambition". Rather, the heroised figure himself would heat his admirers' coals and thus stir them to action; at least that is what the hero-makers had in mind. Accordingly, empowering collective action was what made the marginal men connect to aspiring English warrior nobles: All three had political ideas that they tried to infuse into the heroic figures to which they helped give shape, form and content. Their ideas reached far and wide, and none of them actually achieved much of what they envisaged. But this must not lead us to think that they were actually without importance: By continuously asserting their surprisingly similar positions of an aggressive stance against the Spanish threat to a religiously united Christendom, they either created or supported the positions the Sidney-Essex circle would embrace.

This role can be linked to broader socio-political developments. Sven Externbrink has asserted that the humanists of the European republic of letters were deeply intertwined with the field of diplomacy. ${ }^{149}$ In an exemplary way, this early form of diplomacy without clear state boundaries and with letters as the main means of transmitting information has been traced as a distinct culture for the

146 Gajda, The Earl of Essex and Late Elizabethan Political Culture (footnote 91), p. 10.

147 Essex, An Apologie (footnote 116), p. D4 recto and verso.

148 H. Esser, Soziologie. Spezielle Grundlagen, Bd. 3, Soziales Handeln, Frankfurt am Main 2000, pp. 215-216.

149 Cf. S. Externbrink, Humanismus, Gelehrtenrepublik und Diplomatie. Überlegungen zu ihren Beziehungen in der Frühen Neuzeit, in: H. von Thiessen / C. Windler (eds.), Akteure der Außenbeziehungen. Netzwerke und Interkulturalität im historischen Wandel, Cologne [et al.] 2010, pp. 133-150, here p. 134; K. Garber, A propos de la politisation de l'humanisme tardif européen, in: C. Lauvergnat-Gagnière (ed.), Le juste et l'injuste à la Renaissance et à l'âge classique, St. Etienne 1986, pp. 157-166. 
decades around the year 1600 by Ruth Kohlndorfer-Fries. According to her, the "group of 'learned diplomats' who crisscrossed Europe in the decades around 1600 " were at the core of this peculiar episode of the emerging system of international relations - which would change into a system of clearly delineated institutions by the middle of the $17^{\text {th }}$ century..$^{150}$

These difficult times, shaped by the "struggle for stability", 151 helped create a profoundly militant, antagonistic culture that was not at all halted, stopped or tamed by these marginal, humanistic men - in fact, they strengthened it: They blew the coals of aristocrats' ambitions, not only in matters of mind and knowledge, but just as much in matters of practical politics and broader policy, frequently involving a kind of military language and scope. This was set in the "cold war of the erudites", 152 as Martin Mulsow has called the "cultural competitions"153 in the decades around 1600, just as Marian Füssel has spoken of the republic of letters as a "state of war". 154

\section{Conclusion}

What the marginal men achieved was nothing of the sort they envisaged: Their call to arms did not resonate loudly. Although the Sidney-Essex circle continued for decades after the execution of the earl in 1601 to pursue a militant foreign policy, it never gained decisive impact. Yet what the marginal hero-makers achieved, in contrast, was a lasting cultural impact: The heroic model Sidney and Essex had embodied and thus brought to life continued to serve as the most important heroic pattern for English warrior nobles until the middle of the 17th century, as Roger Manning has shown. ${ }^{155}$

All of the writings considered here were to have an afterlife. The correspondence between Sidney and Languet was printed several times in the $17^{\text {th }}$ century, and Roger Kuin has pointed out that it served as a model for imitation, and "a generation or two later found these letters irresistible”. ${ }^{156}$ There was a paradoxical intended public for these letters from the beginning: On the one hand, they

150 Kohlndorfer-Fries, Diplomatie und Gelehrtenrepublik (footnote 132), pp. 267-268.

151 T. K. Rabb, The Struggle for Stability in Early Modern Europe, New York 1975.

152 M. Mulsow, Die unanständige Gelehrtenrepublik. Wissen, Libertinage und Kommunikation in der Frühen Neuzeit, Stuttgart/Weimar 2007, p. 173.

153 This term is used in a monograph on the Holy Roman Empire, see C. Sittig, Kulturelle Konkurrenzen. Studien zu Semiotik und Ästhetik adeligen Wetteifers um 1600, Berlin/ New York 2010.

154 M. Füssel, Die Gelehrtenrepublik im Kriegszustand. Zur bellizitären Metaphorik in gelehrten Streitkulturen der Frühen Neuzeit, in: Zeitsprünge 15, Issue 2/3, 2011, pp. 158-175.

155 Manning, Swordsmen (footnote 126), pp. 37-40.

156 R. Kuin, A Civil Conversation. Letters and the Edge of Form, in: Z. Lesser / B. S. Robinson (eds.), Textual Conversations in the Renaissance. Ethics, Authors, Technologies, Aldershot 2006, pp. 147-172, here p. 164, p. 170. 
were meant to exclude people who were not able to read Latin and who were not part of the intimate relation. This can be seen from the frequent request in the letters to keep them safe and not let anyone else read them. On the other hand, there was, from the start, the intention to eventually publish this correspondence, which can be assumed from their elaborate style. Thus, the writers were inviting a much larger - if learned - public into these intimate interactions. Quite similar was the situation with the letters written between Essex and Pérez: When Pérez returned to France in 1595 and became a counsellor for Henri IV, he asked Essex to burn the correspondence. However, in 1599, after having broken with Essex, Pérez decided to edit them; a selection of these letters were published in 1601 and proved sought-after reading. ${ }^{157}$ More difficult was the publication of Bruno's works. They had been printed and published already during his stay in England. As the "Expulsion of the Triumphant Beast" sounds in parts like anti-papal propaganda tract, unjustified rumours spread that it was responsible for Bruno's burning in 1600; only in 1713 was John Toland able to print and distribute the work again. ${ }^{158}$ But the continuing usage of his ideas can be traced, for example, in copies from Bruno's works that the ninth Earl of Northumberland, a contemporary courtier of Sidney and Essex, had in his library and had commented on in the margins. ${ }^{159}$ And parts of the "Expulsion" were used for the Stuart court masque "Coelum Britannicum" in 1634. In what way Shakespeare and his plays took cues from Bruno remains subject to speculation. ${ }^{160}$

To return to the hero-makers themselves, there were important differences between these figures. The power structures apparent in their respective relations to the heroised figures let no clear picture emerge: Languet excelled at ordering Sidney around, while Bruno was happy to address Sidney on terms of equality Pérez, in contrast, was extremely deferential to the Earl of Essex. Neither is the grade of intimacy common to all: Languet always remained at a vast physical distance from the Sidney circle, not knowing most of its members personally; Bruno got to know the courtiers, but only during transitory events; Pérez, in turn, lived at the household and shared many a meal and talk with the heroised figure. Maybe it is also because of this lack of physical distance - as Hegel remarked, there is no hero for a valet ${ }^{161}$ - that Pérez chose the grandiose language in cele-

157 Ungerer, A Spaniard in Elizabethan England, Vol. 1 (footnote 55), p. 69; Id., A Spaniard in Elizabethan England, Vol. 2 (footnote 1), p. 298, p. 302.

158 E. Blum / P. R. Blum, Einleitung, in: G. Bruno, Spaccio della bestia trionfante, ed. and transl. E. Blum and P. R. Blum, Hamburg 2009, pp. XLI-XLIII.

159 H. Gatti, Giordano Bruno. The Texts in the Library of the Ninth Earl of Northumberland, in: Journal of the Warburg and Courtauld Institutes 46, 1983, pp. 63-77.

160 Id., Essays on Giordano Bruno, Princeton 2011, p. 143. She remarks on the work done by John Florio to keep Bruno remembered in England.

161 Cf. H. Nagl-Docekal, "Für einen Kammerdiener gibt es keinen Helden". Hegels Kritik an der moralischen Beurteilung "welthistorischer Individuen", in: G. Klingenstein [et al.] (eds.), Biographie und Geschichtswissenschaft, Wien 1979, pp. 68-79; Giesen, Triumph and Trauma (footnote 33), p. 20. 
brating Essex as a hero: His topoi were so far from the ordinary that they made some measure of distance visible. This could also account for the intimacy of Languet's letters to Sidney - this might have become possible as they rarely ever saw each other or shared physical proximity. But no matter how these marginal men positioned themselves in connection to their heroised figures - like Languet, constructing himself as the sympathizing friend and mentor; like Bruno, fashioning himself as a co-heroic figure in the same mould as the warrior-noble; or like Pérez, positioning himself as an intermediary to the glorified, even deified figure of the Earl of Essex -, clearly all of them turned to Sidney or Essex for a reason: They wanted to be safe through the creation and maintenance of a heroic figure whom others would flock to. And they all remained somewhat detached from the heroic figure. Thus, these experts of the threshold also became masters of distance.

What can be gained from this focussing of the margins? It has become clear that eventual circumstances mattered - each and every one of the marginals was in a special and difficult situation in England and urgently needed and was looking for help. Their hero-making was enabled and determined by a specific historical situation which did not occur, for instance, in France, in the same way. Therefore, it should be an interesting task to compare this specific figuration of the English court in the late Elizabethan era with other times and spaces - for instance, the further development of the former Sidney-Essex circle towards the middle of the $17^{\text {th }}$ century, or the French warrior nobility of the same time with its similar aristocratic structure and different cultural and political developments. ${ }^{162}$

At the same time, this study also could be deepened. I have refrained from determining the "circle" surrounding Philip Sidney and the Earl of Essex further. This article focusses on the most articulate of the hero-makers, the marginals, although in this case, the primary audience was co-operative in the making of the heroic figures. What needs more research as well is the connection between the fashionings of the hero-makers and the self-fashionings of the heroised persons that need to be combined. Thus only will it be possible to grasp the ambitious figure of the late Renaissance hero.

162 On the similarity, see J.-M. Constant, La Noblesse en liberté. XVI ${ }^{\mathrm{e}}-\mathrm{XVII}{ }^{\mathrm{e}}$ siècles, Rennes 2004, pp. 57-65. 